\title{
Injera Making Quality Evaluation of Tef and Cassava Composite Flour
}

\author{
Misgana Banti ${ }^{1, *}$, Tegene Atlaw ${ }^{1}$, Bilatu $\operatorname{Agza}^{2}$ \\ ${ }^{1}$ Food Science and Nutrition Research, Jimma Agricultural Research Center, Ethiopian Institute of Agricultural Research, Jimma, Ethiopia \\ ${ }^{2}$ Food Science and Nutrition Research, Ethiopian Institute of Agricultural Research, Addis Ababa, Ethiopia
}

\section{Email address:}

misganabanti2013@gmail.com (M. Banti)

${ }^{*}$ Corresponding author

\section{To cite this article:}

Misgana Banti, Tegene Atlaw, Bilatu Agza. Injera Making Quality Evaluation of Tef and Cassava Composite Flour. American Journal of Bioscience and Bioengineering. Vol. 8, No. 6, 2020, pp. 99-104. doi: 10.11648/j.bio.20200806.11

Received: August 30, 2020; Accepted: September 17, 2020; Published: November 27, 2020

\begin{abstract}
Tef is indigenous Ethiopian cereal crop while cassava is a high carbohydrate-containing crop recently introduced to Ethiopia. Injera is the staple food to Ethiopians mostly prepared from tef as the main ingredient. This was a research done by partially substituting tef, relatively expensive flour, by cassava flour and evaluated its injera making quality. Tef and cassava flours were mixed in all possible ratios at 10\% intervals. Functional properties, sensory evaluations and proximate compositions were estimated using standard methods. Except water absorption capacity, all other functional properties were significantly varied with changing proportion of tef and cassava flours. The sensory acceptability of tef-cassava injera was significantly decreased in all parameters with increasing proportion of cassava flour. Tef-cassava injera contained 7.59 to $9.41 \%$ moisture, 0.65 to $1.87 \%$ ash, 0.40 to $1.02 \%$ crude fat, 3.79 to $11.89 \%$ protein, 1.10 to $3.05 \%$ crude fiber, 75.73 to $83.54 \%$ carbohydrate and 349.45 to 364.45 energy/100g. As cassava flour substitution levels increase, most flour functional properties increased, whereas sensory characteristics and proximate composition parameters (protein, fat, ash and energy) decreased. It was concluded that up to $40 \%$ cassava could be incorporated with tef to make injera with slightly acceptable sensory quality and fair nutritional value. Further research is required with regard to quality of injera as affected by other factors like maturity stages of cassava and the like.
\end{abstract}

Keywords: Tef, Cassava, Injera, Sensory Quality, Functional Property, Proximate Composition

\section{Introduction}

Injera, a fermented flatbread common in Ethiopian culture is mainly made from flour of grain tef (Eragrostis tef (Zucc.) Trotter). This food product is popular in almost whole regions of Ethiopia though the level of consumption may differ to some extent from place to place. It is said to be a staple food in the central, western and northern parts of Ethiopia as well as among the urban community [1]. Though tef is the mainly preferred cereals for injera making, there are other possible sources like wheat, barley, sorghum, millet, maize, and rice to be used just based on the availability. These types of flour sources for injera making can either be tef alone or the combination of the above-listed cereals in addition. From the recent research trends roots and tuber flour can also possibly to be used in the development of this product by partially substituting the above cereals flour.
Cassava among these roots and tuber crops is a flour source with good potential to be evaluated for this partial substitution.

Tef considered superior due to its nutritional merits and the crop is rich in carbohydrate, fiber [2] and contains more iron, calcium and zinc than other cereal grains, including wheat, barley and sorghum [3]. Tef has physico-chemical properties with great potential to be used in a broad range of food applications. Tef's flour has a high water absorption capacity, which relates to the higher degree of swelling of its starches, which have a small and uniform granule size, hence, providing larger surface area [4, 5], Tef starch has a slow retro gradation tendency and hence, it could have a potentially positive impact on the shelf life of baked products. In addition, tef is preferred for making injera in terms of flavor quality, texture and softness $[4,6]$.

On the other hand, Cassava (Manihotesculenta) also known as yucca or manioc is originated in South America. It 
is now widely grown in many parts of Asia and Africa, mainly for its starchy tuberous roots, which may grow to an enormous size. Readily established from cuttings, it is grown in poor soil, requires relatively little attention, and withstands adverse weather conditions. Cassava is a less expensive source of carbohydrate and the energy yield from cassava is often very high, even higher than energy from cereals. It should be encouraged in non-arid areas where nutrition and the main food problems arise from a shortage of total food and deficient energy intake, because of its high yields and other agricultural advantages.

Cassava is recently introduced to Ethiopia, its utilization as a portion of food is not well known and limited to local tradition, cooking the root similar to other roots and tuber crops. Despite this, cassava is among food security crops due to its high yield per unit land which could be as high as $36.5 \mathrm{t} / \mathrm{hec}$ as reported in literatures [7]. Thus, cassava is a crop with high potential to improve food security issues in developing countries including ours. On the contrary to that, tef is of high demand both in domestic and international market due to its high quality including nutritional and health benefit. Therefore, its price is escalating from time to time. Traditional products like injera are almost solely prepared from the crop [8]. In order to minimize the price of products like injera, at least partially substituting tef, highly expensive cereal with relatively less expensive flour sources like cassava is very important. This study was therefore initiated and conducted to evaluate injera making quality of cassava through partially substituting tef flour.

\section{Materials and Methods}

\subsection{Sample Collection and Preparation}

\subsubsection{Cassava Flour Preparation}

Fresh cassava roots (Kello variety) were collected from the horticulture research program of Jimma Agricultural Research center (JARC). The root was washed and the outer layers of the root were peeled by using a sharp stainless steel knife and chopped and soaked in pure water for 48 hours. After the water was drained off, the tuber was sun-dried on mesh for five days till brittle enough for grinding. The dried cassava was then milled into flour and sieved in order to obtain flour with uniform particle size. Finally, the flour was packaged in polypropylene bags until processing and analysis [9].

\subsubsection{Tef Flour Preparation}

Tef (Kuncho variety) was collected from the cereal crop research program of JARC. Tef grain sample was cleaned for any foreign materials (dust, stone, earth tags, chuff, etc) and milled by disk attrition mill to whole flour to the fineness level used traditionally for injera making at the cottage tef grain-milling house (Jimma, Ethiopia). The milled powder was sieved, collected, and packed in dry polyethylene bags until blending.

\subsection{Formulation of Blends}

Tef and cassava flours were mixed in all possible ratios at $10 \%$ intervals as shown in table 1 .

Table 1. Blending ratios of tef and cassava composite flour.

\begin{tabular}{lll}
\hline Treatment & $\begin{array}{l}\text { Component } \mathbf{1} \\
\text { A: Tef flour (\%) }\end{array}$ & $\begin{array}{l}\text { Component 2 } \\
\text { B: Cassava flour (\%) }\end{array}$ \\
\hline 1 & 100 & 0 \\
2 & 90 & 10 \\
3 & 80 & 20 \\
4 & 70 & 30 \\
5 & 60 & 40 \\
6 & 50 & 50 \\
7 & 40 & 60 \\
8 & 30 & 70 \\
9 & 20 & 80 \\
10 & 10 & 90 \\
\hline
\end{tabular}

\subsection{Flours Characterization}

\subsubsection{Water Absorption Capacity (WAC)}

Water absorption capacity was computed as described by [10]. A gram of the blended flour was added into $10 \mathrm{ml}$ distilled water in a weighed centrifuge tube and stir six times by 10 -minute intervals. The sample was centrifuged at $3000 \mathrm{rpm}$ for 25 minutes and the clear supernatant was decanted and re-weight. Change in weight was expressed as a percent of water absorption.

$$
W A C=\frac{\mathrm{W} 3-(\mathrm{W} 1+\mathrm{W} 2)}{\mathrm{W} 1} * 100 \mid
$$

Where $\mathrm{W} 1=$ weight of the sample, W2=weight of the empty centrifuge tube, W3 =Weight of residue after decanting supernatant in centrifuge tub

\subsubsection{Swelling Power}

The swelling power of flour was determined based on the modified method of [11]. A gram of flour sample was transferred to a weighed centrifuge tube and $10 \mathrm{ml}$ of distilled water was added. The sample in the centrifuge tube was stirred gently for 10 minutes by a stirrer and then heated at $90^{\circ} \mathrm{C}$ for 30 minutes. After cooling to room temperature, the samples were centrifuged at $5000 \mathrm{rpm}$ for 10 minutes and weighed after decanting all supernatant from the tube.

$$
\text { Swellingpower }=\frac{\text { weight of sediment paste }}{\text { Weight of sample }} w / w
$$

\subsubsection{Oil Absorption Capacity (OAC)}

To determine the OAC, $1 \mathrm{~g}$ of samples was added to $10 \mathrm{ml}$ of soybean oil in $25 \mathrm{ml}$ of the centrifuge tube. The sample in the tube was stirred for two minutes and then centrifuged at 4000rpm for 20 minutes. The oil formed as the supernatant was separated in a $10 \mathrm{ml}$ cylinder and recorded [11]. 


\subsubsection{Dispersibility}

In order to determine the dispersibility, $10 \mathrm{~g}$ of flour sample was added into a $100 \mathrm{ml}$ measuring cylinder and filled by distilled water up to $100 \mathrm{ml}$ following the method used by [12]. The sample in the measuring cylinder was stirred vigorously and allowed to settle for $3 \mathrm{hrs}$. The Dispersibility was calculated by subtracting the volume of the settled particle from $100 \mathrm{ml}$.

$$
\text { Dispersibility }=100 \mathrm{ml}-\text { Volume of settled particle }
$$

\subsection{Injera Making Procedure}

The injera was made as described by the modified method of [8]. To make injera, 200g of composite flour from each treatment was mixed with $180 \mathrm{ml}$ of water and kneaded for about 5 min. A starter culture (Irsho, 5\% dough saved from previous works) was added and fermented for $48 \mathrm{hrs}$. at room temperature. Part of the dough named Absit ( $80 \mathrm{~g}$ or $10 \%$ ) was mixed with $30 \mathrm{ml}$ of water and cooked in $200 \mathrm{ml}$ boiled water for $1 \mathrm{~min}$, cooled to $45^{\circ} \mathrm{C}$ and added back to the fermenting dough and mixed well. A $100 \mathrm{ml}$ of water was added and the batter fermented for 3-4 hours at room temperature until foam and bubbles formed (second fermentation). About $500 \mathrm{ml}$ of the batter was poured in a circular manner; on a $50 \mathrm{~cm}$ diameter hot clay griddle (Metal) and baked covered for about 2-3 min. the hot fresh injera was drawn from metad. The fresh baked injera was cooled and presented for sensory evaluation. Injera samples were dried for $105^{\circ} \mathrm{C}$ in an oven for proximate analysis.

\subsection{Sensory Evaluation}

A semi-trained panel (a panel briefed about the scoring of degree of liking for sensory attribute) of 50 peoples from JARC (Jimma Agricultural Research center), who have experienced consuming injera has participated. Injera prepared from each treatment were evaluated using a 9 points hedonic scale (1- extremely like, 9 - extremely dislike) [10] in duplication. A rolled piece of injera was presented in two digit-coded plates for panelists on a tray at room temperature within 2 hours after baking. The attributes evaluated were top and bottom surface color, description of eyes, texture, taste and overall acceptability.

\subsection{Proximate Analysis}

International method, Association of Official Analytical Chemists [13] were used to determine crude protein, crude fat, crude fiber, moisture and ash contents of injera samples. Protein content was determined by Kjeldahl (Kjeltec 8400, Auto Sample Systems, Foss, Sweden) using the N conversion factor of 6.25 following the same official method of AOAC. Soxhlet method (Soxtec 8000, Foss, Sweden) was used to extract crude fat. The moisture content was determined by the air convection oven drying method as described by the same method. Ash was determined using the combustion method by a muffle furnace at $550^{\circ} \mathrm{C}$. Total carbohydrate was calculated by difference: 100 - (\% Moisture $+\%$ Crude protein $+\%$ Crude fat $+\%$ Crude fiber $+\%$ Ash) (Onwuka, 2005). Energy value per $100 \mathrm{~g}$ was calculated using the Atwater conversion factors, where $\mathrm{E}(\mathrm{kcal}$ per $100 \mathrm{~g})=[9 \mathrm{X}$ crude fat $(\%)+4 \times$ crude proteins $(\%)+4 \times$ total carbohydrates (\%)] (Maclean et al., 2003).

\subsection{Statistical Analysis}

The data were analyzed by using analysis of variance (ANOVA), at a $95 \%$ level of confidence by the SAS 9.3 version. Separation of the mean values was carried out using Fischer's test, and a significant difference (LSD) between any two means was accepted at $\mathrm{p}<0.05$.

\section{Results and Discussions}

\subsection{Functional Properties of Tef-cassava Composite Flour}

Functional properties of tef-cassava composite flour are presented in Table 2. Except water absorption capacity (WAC), all other functional properties were significantly varied with changing proportion of tef and cassava flours. The water absorption capacity of the flour was ranged from $105.35-156.90 \%$ and the finding was in agreement with [8]. WAC of the tef-cassava composite flour generally was high and flours with high water absorption capacity have more hydrophilic constituents such as polysaccharides. The high WAC of the composite flour helps the processors to add more water during processing, and might be important to maintain freshness of the product [14].

Swelling power ranging from $3.60 \%-6.10 \%$ were reported as indicated in table 2 below. According to Eriksson (2014), swelling power expressed as the weight of sediment per gram of starch; the maximum increase in volume and weight the starch undergoes when heating in excess water. This property of flour is reported to be related with the eating quality of food and hence the higher the swelling power the better will be eating quality of food [11].

Oil absorption capacity is the indication of the emulsifying capacity and amount of oil uptake by a sample during food processing like frying [11]. It is the property mostly related with sensory property of a product like flavor, taste and aroma. The oil absorption capacity reported in this study varied from $111.0 \%$ to $160.0 \%$. The oil absorption capacity of tef flour alone was score lowest value (115.0) and the highest oil absorption capacity was recorded for $70 \%$ cassava flour in the blended ratio. Authors in [15] reported that high oil absorption capacities of flour could improve the property of other flour during formulation development.

Dispersibility is a measure of the reconstitution of flour or starch in water. The higher the dispersibility, the better the sample reconstitutes in water [16]. The lower the dispersibility of flour samples is probably the indication of lump formation tendency during preparation [12]. The dispersibility of blend flour in this study ranged between 68.5 and 76.5. Tef flour without cassava had the highest dispersibility (76.50) and blending ratio of $30 \%$ tef and $70 \%$ cassava flour had the lowest dispersibility (68.50). Tef flour 
had the best reconstitution ability than all-composite flour proportions with cassava flour.

Table 2. Functional property results of tef-cassava composite flour.

\begin{tabular}{lllll}
\hline Treatment & Water absorption capacity & Swelling power & Oil absorption capacity & Dispersibility \\
\hline 1 & $123.40^{\mathrm{a}}$ & $3.60^{\mathrm{b}}$ & $115.00^{\mathrm{d}}$ & $76.50^{\mathrm{a}}$ \\
2 & $127.80^{\mathrm{a}}$ & $6.10^{\mathrm{a}}$ & $145.00^{\mathrm{ab}}$ & $75.00^{\mathrm{ab}}$ \\
3 & $124.40^{\mathrm{a}}$ & $5.00^{\mathrm{ab}}$ & $145.00^{\mathrm{ab}}$ & $72.50^{\mathrm{bc}}$ \\
4 & $127.70^{\mathrm{a}}$ & $4.00^{\mathrm{b}}$ & $135.00^{\mathrm{bc}}$ & $74.00^{\mathrm{abc}}$ \\
5 & $132.65^{\mathrm{a}}$ & $3.70^{\mathrm{b}}$ & $115.00^{\mathrm{d}}$ & $72.50^{\mathrm{bc}}$ \\
6 & $126.30^{\mathrm{a}}$ & $3.80^{\mathrm{b}}$ & $145.00^{\mathrm{ab}}$ & $72.00^{\mathrm{bcd}}$ \\
7 & $125.35^{\mathrm{b}}$ & $3.80^{\mathrm{b}}$ & $120.00^{\mathrm{cd}}$ & $71.50^{\mathrm{bcd}}$ \\
8 & $140.40^{\mathrm{a}}$ & $4.20^{\mathrm{b}}$ & $160.00^{\mathrm{a}}$ & $68.50^{\mathrm{d}}$ \\
9 & $156.90^{\mathrm{a}}$ & $135.00^{\mathrm{bc}}$ & $75.00^{\mathrm{ab}}$ \\
10 & $137.00^{\mathrm{a}}$ & $4.50^{\mathrm{b}}$ & $150.00^{\mathrm{ab}}$ & $71.00^{\mathrm{cd}}$ \\
Mean & 125.19 & 136.50 & 72.85 \\
CV $(\%)$ & 13.76 & 4.27 & 5.70 & 2.24 \\
\hline
\end{tabular}

Means with the same letter in a column are not significantly different ( $\mathrm{p}>0.05), \mathrm{T}_{1}=100 \%$ tef, $\mathrm{T}_{2}=90 \%$ tef \& $10 \%$ cassava, $\mathrm{T}_{3}=80 \%$ tef $\& 20 \%$ cassava, $\mathrm{T}_{4}=70 \%$ tef \& $30 \%$ cassava, $\mathrm{T}_{5}=60 \%$ tef \& $40 \%$ cassava, $\mathrm{T}_{6}=50 \%$ tef \& $50 \%$ cassava, $\mathrm{T}_{7}=40 \%$ tef $\& 60 \%$ cassava, $\mathrm{T}_{8}=30 \%$ tef $\& 70 \%$ cassava, $\mathrm{T}_{9}=20 \%$ tef $\& 80 \%$ cassava, $\mathrm{T}_{10}=10 \%$ tef $\& 90 \%$ cassava

\subsection{Sensory Properties of Tef-cassava Injera}

The sensory acceptability of tef-cassava injera was significantly decreased in all parameters with increasing proportion of cassava flour. A similar report by [8] also indicated that the sensory quality of injera declined with an increasing proportion of cassava flour. Even though the difference in sensory acceptance is significantly declining with addition of cassava, incorporation of cassava flour as high as $30 \%$ was moderately acceptable. Even the $40 \%$ inclusion level is slightly liked in color and eye description, but neither liked nor disliked in taste, texture and overall acceptability. These indicate that it is possible to prepare injera by incorporation of up to $40 \%$ cassava flour with tef flour with acceptable sensory quality.

Table 3. Sensory properties of tef-cassava composite injera.

\begin{tabular}{llllll}
\hline Treatments & Top and bottom surface color & Eye description & Texture & Test and after the test & Overall acceptability \\
\hline 1 & $1.35 \mathrm{f}$ & $1.50 \mathrm{f}$ & $1.76 \mathrm{~d}$ & $2.18 \mathrm{e}$ & $1.86 \mathrm{f}$ \\
2 & $2.21 \mathrm{ef}$ & $1.88 \mathrm{f}$ & $2.36 \mathrm{~d}$ & $2.49 \mathrm{de}$ & $2.35 \mathrm{f}$ \\
3 & $3.16 \mathrm{ed}$ & $3.81 \mathrm{e}$ & $3.89 \mathrm{c}$ & $3.29 \mathrm{~d}$ & $4.28 \mathrm{e}$ \\
4 & $4.22 \mathrm{~cd}$ & $4.29 \mathrm{de}$ & $4.62 \mathrm{bc}$ & $4.85 \mathrm{c}$ & $4.93 \mathrm{cde}$ \\
5 & $4.68 \mathrm{bc}$ & $4.96 \mathrm{~cd}$ & $4.77 \mathrm{~b}$ & $5.06 \mathrm{bc}$ & $4.54 \mathrm{de}$ \\
6 & $5.27 \mathrm{bc}$ & $5.35 \mathrm{c}$ & $5.00 \mathrm{~b}$ & $5.15 \mathrm{bc}$ & $5.39 \mathrm{bcd}$ \\
7 & $5.75 \mathrm{~b}$ & $5.52 \mathrm{c}$ & $5.27 \mathrm{~b}$ & $5.21 \mathrm{bc}$ & $5.54 \mathrm{bc}$ \\
8 & $7.03 \mathrm{a}$ & $6.34 \mathrm{~b}$ & $6.47 \mathrm{a}$ & $6.40 \mathrm{a}$ & $6.56 \mathrm{a}$ \\
9 & $7.40 \mathrm{a}$ & $7.07 \mathrm{ab}$ & $6.15 \mathrm{a}$ & $5.89 \mathrm{ab}$ & $6.56 \mathrm{a}$ \\
10 & $7.97 \mathrm{a}$ & $7.47 \mathrm{a}$ & $6.62 \mathrm{a}$ & $6.53 \mathrm{a}$ & $6.24 \mathrm{ab}$ \\
$\mathrm{CV}$ & 10.57 & 6.92 & 8.12 & 9.32 & 8.28 \\
$\mathrm{LSD}$ & 1.17 & 0.75 & 0.86 & 0.99 & 0.90 \\
\hline
\end{tabular}

Means with the same letter in a column are not significantly different $(p>0.05)$, nine hedonic scale were used for sensory evaluation (1 like extremely to 9 extremely dislike). $\mathrm{T}_{1}=100 \%$ teff, $\mathrm{T}_{2}=90 \%$ teff \& $10 \%$ cassava, $\mathrm{T}_{3}=80 \%$ teff \& $20 \%$ cassava, $\mathrm{T}_{4}=70 \%$ teff \& $30 \%$ cassava, $\mathrm{T}_{5}=60 \%$ teff \& $40 \%$ cassava, $\mathrm{T}_{6}=50 \%$ teff \& $50 \%$ cassava, $\mathrm{T}_{7}=40 \%$ teff \& $60 \%$ cassava, $\mathrm{T}_{8}=30 \%$ teff \& $70 \%$ cassava, $\mathrm{T}_{9}=20 \%$ teff \& $80 \%$ cassava, $\mathrm{T}_{10}=10 \%$ teff \& 90 casssava.

\subsection{Proximate Composition of Tef-Cassava Injera}

The proximate composition of tef-cassava injera is presented in table 4.

Moisture content of tef-cassava injera was in the range of $7.59-9.41 \%$ and had shown a slight increment as the proportion of cassava increased. However, the increment was not significant statistically. This might be due to the high water absorption capacity of cassava flour (Table 2).

Ash content of injera prepared from $100 \%$ tef flour was $1.87 \%$ and the same parameter reduced to $1.04 \%$ at $10 \%$ cassava substitution. This result was in line with [8] where the author reported tef flour had higher ash content than cassava flour. The fat content estimated in this study is generally low (0.23-1.54\%), and the value had shown a decreasing trend with increasing level of cassava flour which might be due to higher fat content of tef than cassava.

The blending of cassava flour had a significant $(\mathrm{p}<0.05)$ effect on the protein content of blended injera. The addition of more cassava flour had reduced the protein content of injera. The protein content of injera had decreased from 11.89 for $100 \%$ tef to $3.79 \%$ for $90 \%$ cassava containing injera that might be due to the higher protein content of tef than cassava. This may be attributed to the general low protein content of roots and tuber crops including cassava. 
The fiber content of blend injera was in the range between content as level of cassava increase in the proportions. $1.10-3.05 \%$. There was also a decreasing trend in fiber

Table 4. Proximate and energy contents of tef-cassava composite injera (\%).

\begin{tabular}{|c|c|c|c|c|c|c|c|}
\hline Treatment & Moisture & Ash & Crude fat & Protein & Crude fiber & Carbohydrate & Energy \\
\hline 1 & $7.59^{\mathrm{a}}$ & $1.87^{\mathrm{a}}$ & $1.02^{\mathrm{abc}}$ & $11.89^{\mathrm{a}}$ & $3.05^{\mathrm{a}}$ & $75.26^{d}$ & $357.74^{\mathrm{ab}}$ \\
\hline 2 & $7.61^{\mathrm{a}}$ & $1.41^{\text {bcd }}$ & $1.21^{\mathrm{ab}}$ & $10.07^{\mathrm{ab}}$ & $1.97^{\mathrm{f}}$ & $75.72^{\mathrm{d}}$ & $362.12^{\mathrm{a}}$ \\
\hline 3 & $9.41^{\mathrm{a}}$ & $1.825^{\mathrm{ab}}$ & $1.54^{\mathrm{a}}$ & $9.07^{\mathrm{abc}}$ & $2.45^{\mathrm{de}}$ & $77.75^{\mathrm{cd}}$ & $352.98^{\mathrm{bc}}$ \\
\hline 4 & $7.66^{\mathrm{a}}$ & $1.87^{\mathrm{a}}$ & $1.38^{\mathrm{a}}$ & $8.10^{\mathrm{de}}$ & $1.10^{\mathrm{g}}$ & $82.45^{\mathrm{ab}}$ & $364.45^{\mathrm{a}}$ \\
\hline 5 & $8.55^{\mathrm{a}}$ & $1.55^{\mathrm{abc}}$ & $0.90^{\mathrm{abcd}}$ & $7.62^{\text {bcd }}$ & $2.42^{\mathrm{e}}$ & $78.98^{\mathrm{bcd}}$ & $354.45^{\mathrm{bc}}$ \\
\hline 6 & $9.27^{\mathrm{a}}$ & $0.65^{\mathrm{e}}$ & $0.68^{\mathrm{bcd}}$ & $6.07^{\text {cde }}$ & $2.75^{\mathrm{b}}$ & $80.59^{\mathrm{abc}}$ & $352.70^{\mathrm{bc}}$ \\
\hline 7 & $8.81^{\mathrm{a}}$ & $1.27^{\mathrm{cd}}$ & $0.53^{\mathrm{cd}}$ & $5.43^{\mathrm{de}}$ & $2.56^{\mathrm{c}}$ & $81.40^{\mathrm{abc}}$ & $352.11^{b c}$ \\
\hline 9 & $8.39^{\mathrm{a}}$ & $1.29^{\mathrm{cd}}$ & $0.46^{\mathrm{cd}}$ & $5.56^{\text {bcd }}$ & $2.54^{\text {cd }}$ & $83.54^{\mathrm{a}}$ & $353.46^{\mathrm{bc}}$ \\
\hline 10 & $8.75^{\mathrm{a}}$ & $1.04^{\mathrm{de}}$ & $0.23^{\mathrm{d}}$ & $3.79^{\mathrm{e}}$ & $2.38 \mathrm{e}$ & $78.84^{\text {bcd }}$ & $349.83^{c}$ \\
\hline Mean & 8.51 & 1.4 & 0.83 & 7.18 & 2.4 & 79.68 & 354.93 \\
\hline CV (\%) & 11.32 & 14.19 & 15.91 & 19.72 & 1.96 & 2.13 & 0.91 \\
\hline
\end{tabular}

Means with the same letter in a column are not significantly different $(p>0.05), \mathrm{T}_{1}=100 \%$ teff, $\mathrm{T}_{2}=90 \%$ teff $\& 10 \%$ cassava, $\mathrm{T}_{3}=80 \%$ teff $\& 20 \%$ cassava, $\mathrm{T}_{4}=70 \%$ teff \& $30 \%$ cassava, $\mathrm{T}_{5}=60 \%$ teff \& $40 \%$ cassava, $\mathrm{T}_{6}=50 \%$ teff \& $50 \%$ cassava, $\mathrm{T}_{7}=40 \%$ teff $\& 60 \%$ cassava, $\mathrm{T}_{8}=30 \%$ teff \& $70 \%$ cassava, $\mathrm{T}_{9}=20 \%$ teff $\& 80 \%$ cassava, $\mathrm{T}_{10}=10 \%$ teff $\& 90$ cassava. Energy $(\mathrm{kcal} / 100 \mathrm{~g})=[9 \times$ fat $(\%)+4 \mathrm{x}$ protein $(\%)+4 \mathrm{x}$ carbohydrates $(\%)]$.

The carbohydrate content of injera had an increasing trend for every $10 \%$ addition of cassava flour. However, the increment was not linear, and the lowest carbohydrate (75.26\%) was recorded for control injera (100\% tef) while the highest $(83.54 \%)$ was recorded at $80 \%$ cassava. This increase in carbohydrate content may be attributed to high carbohydrate composition of cassava as is in other roots and tuber crops.

Similarly, there was a decreasing trend in energy value of injera as the proportion of cassava in the blend is increased. This is attributed to the higher fat and protein content of tef as compared with that of cassava. Nevertheless, the energy contents of the blended injeras were high in all proportions because of the high carbohydrate of cassava as it is true in other roots and tuber crops. In general, the effect of cassava flour addition is not as such a concern on fat, fiber, carbohydrate and energy contents of tef injera. rather, sensory acceptability is more important factor to determine the substitution level of cassava in injera making.

\section{Conclusion and Recommendation}

This study showed that cassava flour can be a good ingredient to prepare injera together with tef and diversify Ethiopian diet. As cassava flour substitution levels increase, most flour functional properties including water absorption capacity, swelling power and oil absorption capacity increased, whereas sensory characteristics and some proximate composition parameters (protein, fat, ash and energy) were slightly decreased. From this study, it may be concluded that up to $40 \%$ cassava could be incorporated with tef to make injera with slightly acceptable sensory quality and fair nutritional quality.

In the current study standard tef injera preparation procedure was used to process the tef-cassava flour blend. However, some process modification might be required to adjust cassava incorporation. Further investigation is also required to assess the influence of various maturity stages during cassava harvesting and its post-harvest storage on injera quality.

\section{References}

[1] Yassin H. and Getu T., 2019. Effect of Blending Ratio of Red Teff and Potato on the Sensory Quality of Injera. Journal of Food Processing and Technology. 10 (5), 1-4.

[2] NRC (National Research Council of the USA), 1996. Lost Crops of Africa, vol. 1. Grains. National Academy Press, Washington, D. C, pp. 215-234.

[3] Agza B, Ruth Bekele, Legesse Shiferaw. 2018. Quinoa (Chenopodium quinoa, Wild.): as a potential ingredient of injera in Ethiopia, Journal of Cereal Science, doi: 10.1016/j.jcs.2018.06.009.

[4] Bultosa, G., Hall, A. N., and Taylor, J. R., 2002. Physicochemical characterization of grain tef [Eragrostistef (Zucc.) Trotter] starch. Starch Stärke, 54 (10), 461-468.

[5] Bultosa, G., 2007. Physicochemical characteristics of grain and flour in 13 tef [Eragrostistef (Zucc.) Trotter] grain varieties. Journal of Applied Sciences Research, 3 (12), 20422050 .

[6] Zegeye, A., 1997. Acceptability of injera with stewed chicken. Food quality and preference, 8 (4), 293-295.

[7] Belay Yabo and Yared Dagne, "Agronomic research achievements and findings of taro and cassava crops in Ethiopia, A Review. Journal of Agronomy, 14 (1): 1-5.," 2015.

[8] Beruk B. D. and Fasil T. D.., 2017. Effect of Blending Ratio on Proximate Composition, Physico-Chemical Property, and Sensory Acceptability of Injera Produced from Red Tef (Eragrostistef) and Cassava (Manihotesculenta). Food Science and Quality Management www.iiste.org ISSN 2224-6088 (Paper) ISSN 2225-0557 (Online) Vol. 68.

[9] Emmanuel O., Onadipe O., Sébastienne D., Centre S., Egounlety M., Detouc N., Guy M., 2012. Processing of Cassava into Gari and High Quality Cassava Flour In West Africa. Training manual. 19-31. 
[10] Iwe, M. O., Michael, N., Madu, N. E., Obasi, N. E., Onwuka, G. I., Nwabueze, T. U. and Onuh, J. O. 2012. Physicochemical and pasting properties high-quality cassava flour (HQCF) and wheat flour blends. Agrotechnology, 6 (2), 1-8.

[11] Falade, K. O. and Christopher, A. S., 2015. Physical, functional, pasting and thermal properties of flours and starches of six Nigerian rice cultivars. Food Hydrocolloids, 44, pp. 478-490.

[12] Oluwole, O., Akinwale, T., Adesioye, T., Odediran, O., Anuoluwatelemi, J., Ibidapo, O. and Kosoko, S., 2016. Some functional properties of flours from commonly consumed selected Nigerian Food Crops. International Journal of Agricultural and Food Sciences, 1 (5): 92-98.

[13] AOAC, 2016. Official Methods of Analysis of the Association of Official Analytical Chemists, 20thedn. Washington, DC: AOAC International.

[14] Kumar, V., Sharma, H. K., Kaushal, P. and Singh, K., 2015. Optimization of taro-wheat composite flour cake using Taguchi technique. Journal of Food Measurement and Characterization, 9 (1), pp. 35-51.

[15] Sharma, H. K., Njintang, N. Y., Singhal, R. S. and Kaushal, P., 2016. Tropical Roots and Tubers: Production, Processing and Technology. Department of Food Engineering and Technology, Sant Longowal Institute of Engineering and Technology, Sangrur, India, 611p.

[16] Adebowale, A. A., Sanni, L. O. and Fadahunsi, E. L., 2011. Functional and pasting properties of cassava-sweetpotato starch blends. African Journal of Root Tuber Crop, 9 (1), 6-10. 